\title{
SHEDDING SOME LIGHT ON THISMIA RODWAYI F. MUELL. (FAIRY LANTERNS) IN TASMANIA: DISTRIBUTION, HABITAT AND CONSERVATION STATUS
}

\author{
by N. Roberts, M. Wapstra, F. Duncan, A. Woolley, J. Morley and N. Fitzgerald
}

(with one plate, five tables, four text-figures and one appendix)

\begin{abstract}
Roberts, N., Wapstra, M., Duncan, F., Woolley, A., Mor.ey, J. \& Fitzgerald, N., 2003 (19.xii): Shedding some light on Thismia rodwayi F. Muell. (fairy lanterns) in Tasmania: distribution, habitat and conservation status. Papers and Proceedings of the Royal Society of Tasmania 137: 55-66. https://doi.org/10.26749/rstpp.137.55 ISSN 0080-4703. Forest Practices Board, 30 Patrick Street, Hobart, Tasmania 7000, Australia (NR, MW*, FD); Forestry Tasmania, GPO Box 207, Hobart, Tasmania 7001, Australia (AW, JM); Department of Primary Industries, Water and Environment, PO Box 46, Kings Meadows, Tasmania 7249, Australia (NF).* Author for correspondence.
\end{abstract}

\begin{abstract}
Thismia rodwayi is a seldom-seen, subterranean plant that occurs in Tasmania, the eastern states of the Australian mainland and New Zealand. Surveys for the species were prompted by a new record from Archers Sugarloaf near Meander in Tasmania's central north. Several new populations of the species were subsequently discovered in wet eucalypt forests dominated by Eucalyptus obliqua, E. regnans, E. delegatensis or E. viminalis, with an understorey dominated by Pomaderris apetala, Bedfordia salicina and/or Olearia argophylla. The species is now known from the Meander, Glen Huon, Little Denison River, Mount Field, Mount Wellington and Ben Lomond areas. Analysis of current information suggests that the listing of T. rodwayi under Schedule 5 (Rare) of the Tasmanian Threatened Species Protection Act 1995 is appropriate.
\end{abstract}

\section{INTRODUCTION}

Thismia rodwayi F. Muell. is an herbaceous flowering plant with an unusual subterranean habit(pl. 1, fig. 1). It is a member of the largely saprophytic monocot family Burmanniaceae, which includes over 120 species worldwide, most of which occur in the tropics and subtropics.

Since the holotype of $T$. rodwayi was collected in Tasmania in 1890, the species has been recorded in Victoria, New South Wales, Queensland and New Zealand (Willis 1970, Moore \& Edgar 1976, Conn 1994). It is currently listed under Schedule 5 (Rare) of the Tasmanian Threatened Species Protection Act 1995, and it has been similarly listed in other states under equivalent legislation. Two other species of Thismia occur on the Australian mainland ( $T$. clavarioides Thiele \& Jordan, 2002; T. yorkensis Cribb, 1995).

The discovery of $T$. rodwayi in the Archers Sugarloaf area near Meander in November 2002 provided an opportunity to assess its habitat requirements, wider distribution and conservation status. This paper reports on the ecology and distribution of the species, particularly in the Meander area, and provides an overview of information on the species.

\section{TAXONOMY, MORPHOLOGY AND BIOLOGY}

Thismia rodwayi has been known by various scientificepithets (most honouring the collectors of this charismatic plant) including Bagnisia rodwayi, B. hillii, Rodwaya thismiacea, Sarcosiphon hilliiand S. rodwayi (Jonker 1938). The common name ascribed to Thismiarodwayi is 'fairy lanterns'. This name aptly describes the appearance of the small, orange and red, fleshy flowers that barelypenetrate the soil surface and are typically covered by leaf-litter. These brightly-coloured flowers are $10-18 \mathrm{~mm}$ in length and have an obovate longitudinally striped floral tube (the 'lantern'), surmounted by six perianth lobes - the inner three arching inward and cohering at the top, and outer lobes spreading (pl. 1, fig. 1). The vegetative part of the plant is entirely subterranean and is colourless. The roots are about $1-1.5 \mathrm{~mm}$ thick and $4-15 \mathrm{~cm}$ long. They give rise to erect flower stems $(0.5-3 \mathrm{~cm})$, which bear about six colourless leaf-like bracts, which increase in size toward the terminal flower (Conn 1994). The plant lacks chlorophyll and is therefore incapable of photosynthesis. It is commonly considered a saprophyte, although this term

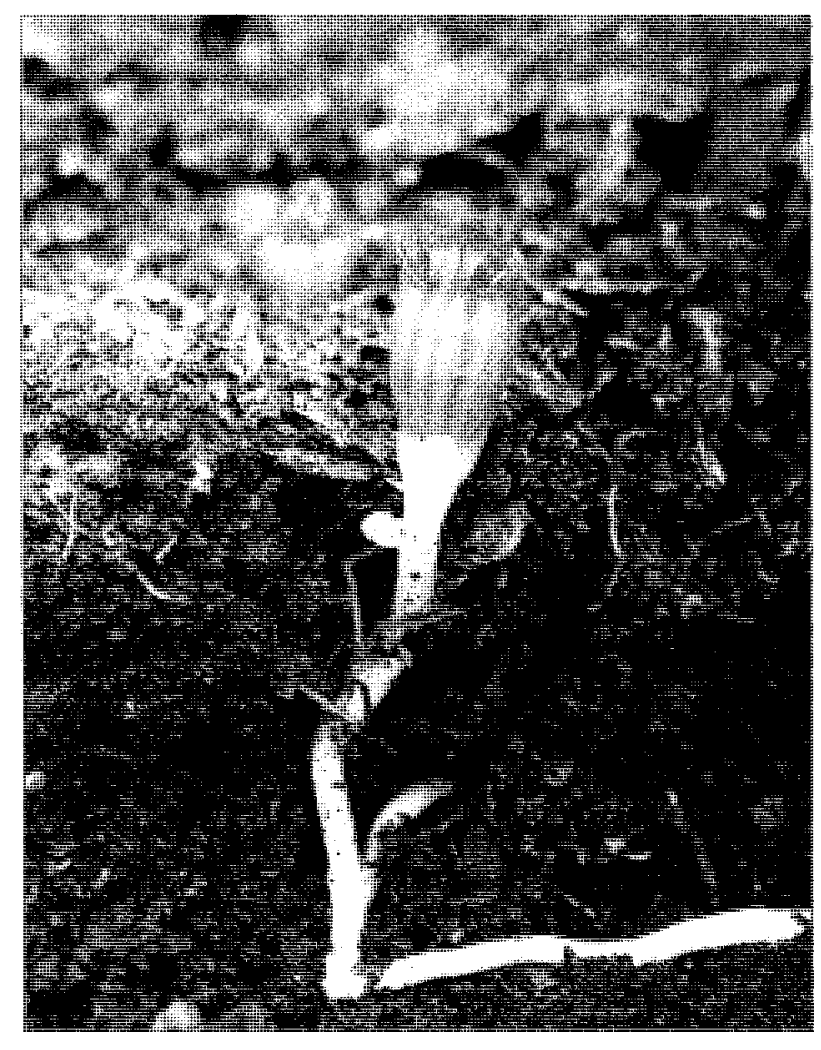

PLATE 1

Thismia rodwayi in situ, showing growth habit (note: surface leaf litter has been removed). 


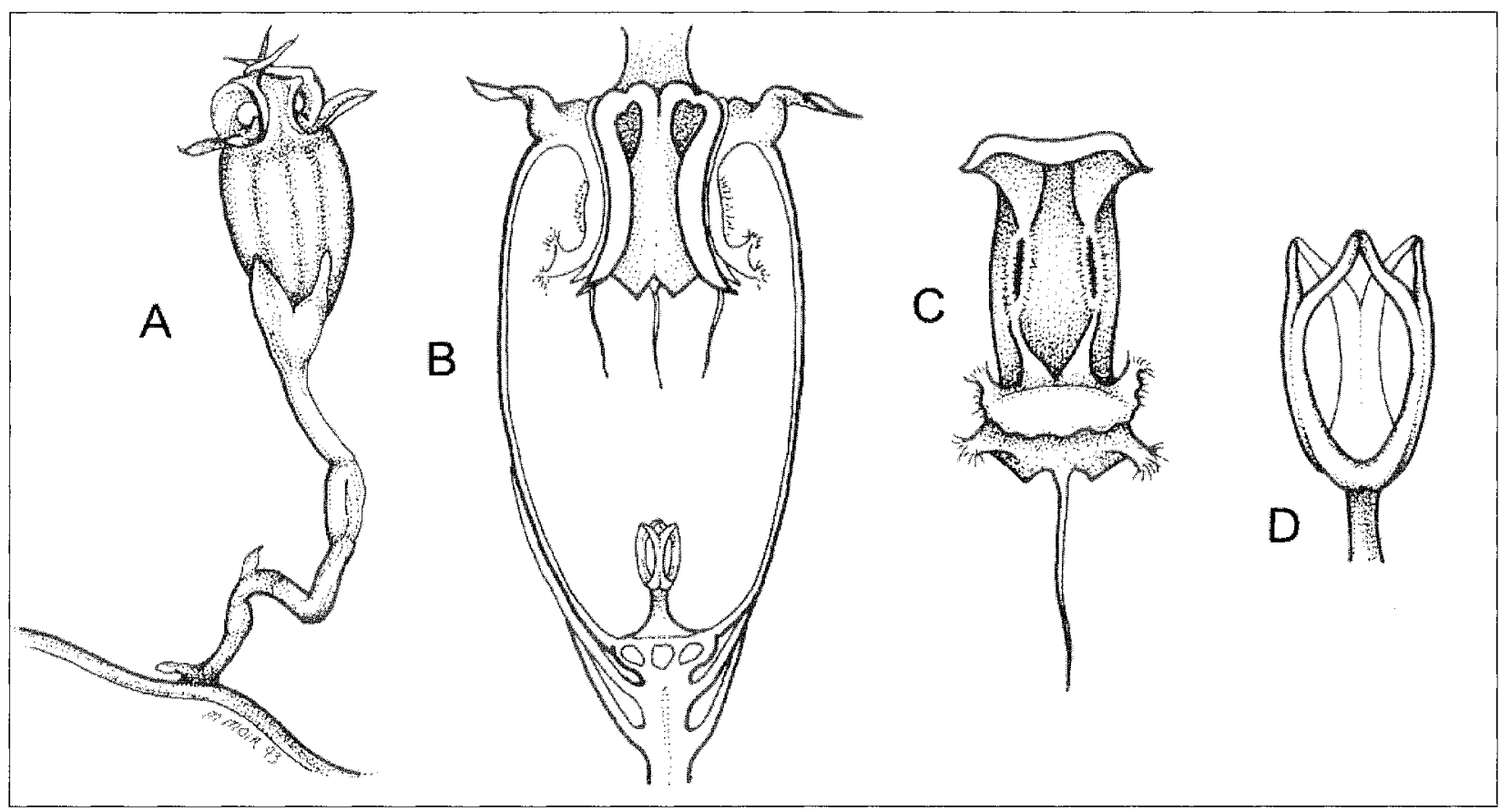

FIG. 1 - Thismia rodwayi. (A) habit x2; (B) flower, longitudinal section, $x 4$; (C) stamen $x 6$; (D) style and stigmas $x 10$. Original line drawing by M. Moir, used with permission from Conn (1994). It should be noted that this line drawing is based on the drawing of Coleman (1936) and there may be some inaccuracy around the style detail in the longitudinal section.

is slightly misleading as it derives its energy from a fungus - the fungus being the true saprophyte.

As in most saprophytic plants, the fungal hyphae exist inside some of the root cells of Thismia plants, and convert rotting material into sugars using specialised enzymes. The plant can obtain carbohydrates by digesting the fungus (known as an endophyte). McLennan (1958) studied the relationship of $T$. rodwayi with its endophyte. Most of the cells in the root cortex were occupied by fungal hyphae, and a cobwebby coating of hyphae was also mixed with humus around the root. Sectioning of the root at intervals from the growing tip revealed that the fungus inside the cortex cells accumulates fat globules in hyphal bladders, which discharge their contents into their host cells, presumably due to a digestive action of the host. The fat globules appear to be converted into a polysaccharide, probably glycogen (McLennan 1958).

A similar study of T. rodwayi in New Zealand (Campbell 1968) also found this type of hyphal infection, with rhizomorphs (root-like aggregations of hyphae) also able to infect the roots of Thismia. The fungus that occupies the roots of $T$. rodwayi (either as hyphae or rhizomorphs) in New Zealand is largely an inhabitant of dead parenchyma cells among layers of corky bark of the trees typically growing near T. rodwayi populations (Campbell 1968). Such an association with the surrounding vegetation has not been established for the endophyte of T. rodwayi in Australia.

\section{ECOLOGY AND DISTRIBUTION}

Much of the current information on the habitat and distribution of T. rodwayi is anecdotal (e.g., Coleman 1936, 1941), and the reproductive biology and life-cycle are poorly understood. Pollination and dispersal agents, flowering interval and germination conditions are largely speculative. One source states that flowering occurs from spring to autumn, and fruits (fleshy cup-shaped capsules) are borne on the plant during summer and autumn (CCRPL 2002). This source also notes that the species occurs in several vegetation types on different geologies, but cool, moist, humic soils are favoured. Conn (1994: 739) states that the preferred habitat of this species is "damp humus and leaf litter in deeply shaded tall forests and fern gullies". Curtis \&Morris (1994: 424) note that the species is "seldom seen but widespread in damp humus and litter in wet forests, recorded in association with roots of Bedfordia salicina, Olearia argophylla and Coprosmaquadrifida" but make no mention of the season or duration of flowering. Rodway (1903:208) indicated that the species was known only from a "gully on [the] eastern slope of Mount Wellington", his original collection site, where he recorded the species was associated with the roots of Olearia argophylla. Rodway (1903) stated that the species flowers from December to January. It is not known whether Rodway's comment was based on his own ongoing observations of the original population; there have been no subsequent Tasmanian records of $T$. rodwayi flowering in January.

\section{HISTORICAL RECORDS OF THISMIA RODWAYI IN TASMANIA}

Until the present study, there were only four records of $T$. rodwayi held by the Tasmanian Herbarium (table 1, fig. 2): from the lower slopes of Mount Wellington (1890), Mount Field (1923), Little Denison River (1968) and Lenah Valley (2002). The species was described by Baron Ferdinand von Mueller in 1890 (von Mueller 1890b) from specimens collected by Leonard Rodway in Tasmania from "near the Derwent". Baron von Mueller was astonished that a Thismia species was found in such temperate latitudes, stating: "... not as might have been looked for in North-Eastern Australia, 


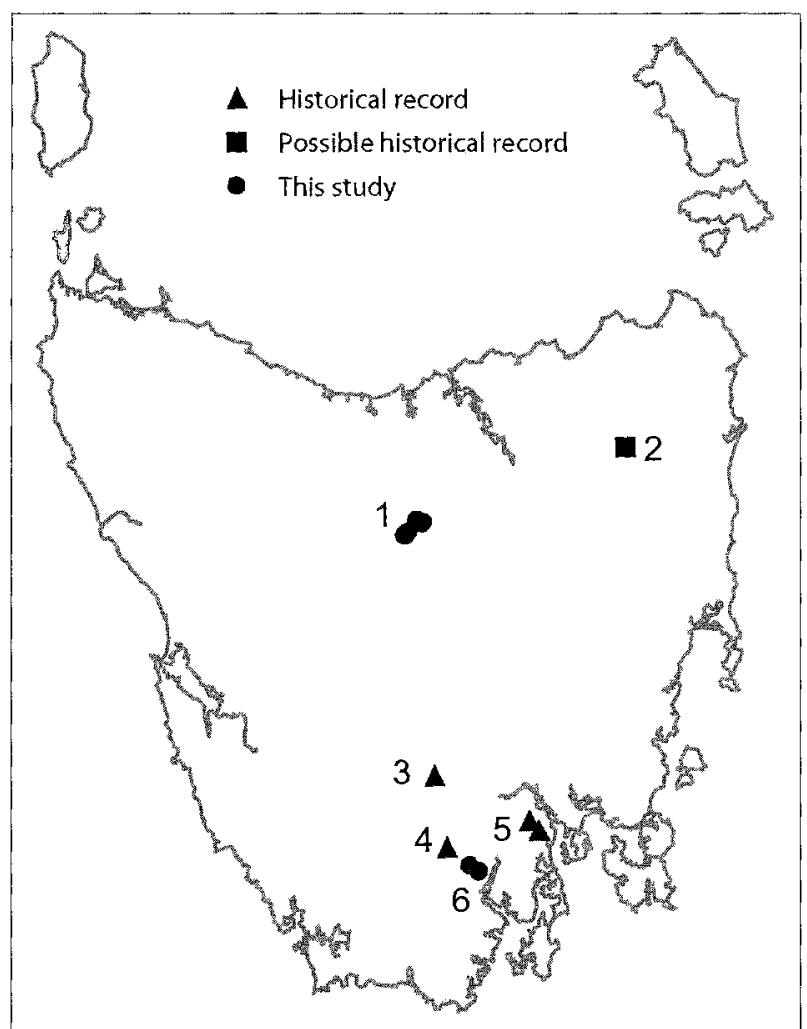

FIG. 2 - Known distribution of Thismia rodwayi in Tasmania. Numbers refer to areas of the State mentioned in the text: 1. Meander area (including Archers Sugarloaf); 2. Ben Lomond area; 3. Mt Field area; 4. Little Denison River area; 5. Mt Wellington area; 6. Glen Huon area (note that the possible site from the 1980s is not shown for clarity - see text for details). but in such an extreme extratropic isolation, is one of the most remarkable additions to our recent knowledge in this direction" (von Mueller 1890a: 234). A letter from Sir Joseph Hooker to Baron von Mueller, found in the folder containing specimens of $T$. rodwayi from Tasmania at the Melbourne Herbarium contains the following passage (source: Coleman 1936: 164): "T have this morning received your account of the Tasmanian Thismia - it is really like a dream: since any preconceived idea of that genus turning up there would have been scouted by every reasoning naturalist who heard it. Had it been fossilized only it would have revolutionized [our idea of? (D.C.)] the former climate of the Southern Hemisphere".

Curtis \& Morris (1994) indicate that T. rodwayi occurs in the Ben Lomond, South West, Mount Field and Mount Wellington floristic regions (Orchard 1988) of Tasmania. The illustration of the species in Curtis \& Morris (1994) is based on a specimen from the Ben Lomond region but this specimen was not curated and therefore does not appear on the herbarium records (A. Buchanan, pers. comm.). The species was also reliably observed from the Neika area on the slopes of Mount Wellington in the 1980s (R. Jones, pers. comm.), and plants delivered to the Tasmanian Herbarium but none of these specimens is in the current collection.

\section{METHODS}

\section{Collation of Known Records}

Historical records for T. rodwayi were collated from a variety of sources including database searches (e.g., DPIWE's GTSpot database) and herbaria including the Tasmanian Herbarium (HO) and the National Herbarium of Victoria (MEL). Personal communication with numerous botanists, naturalists and other field workers who may have seen the species (such as those who regularly survey for litter invertebrates) was also undertaken.

TABLE 1

Historical records of Thismia rodwayi held by the Tasmanian Herbarium (HO)

\begin{tabular}{|c|c|c|c|c|}
\hline Locality ${ }^{1}$ & Date & Collector & $\begin{array}{l}\text { Latitude, } \\
\text { longitude }\end{array}$ & $\begin{array}{l}\mathrm{HO} \\
\text { number }\end{array}$ \\
\hline Cascades, Hobart ${ }^{2}$ & Dec $1890^{4}$ & L. Rodway & $42^{\circ} 54^{\prime}, 147^{\circ} 17^{\prime}$ & 25468 \\
\hline Mt Field track [Lake Dobson Road] & Nov 1923 & L. Rodway & $42^{\circ} 41^{\prime}, 146^{\circ} 42^{\prime}$ & 23812 \\
\hline $\begin{array}{l}\text { Link Road between Russell River Road and Little } \\
\text { Denison River }{ }^{3}\end{array}$ & $20 / 10 / 1968$ & B. Reid \& W.M. Curtis & $42^{\circ} 58^{\prime}, 146^{\circ} 46^{\prime}$ & 115634 \\
\hline Little Denison River, via Judbury ${ }^{3}$ & 1968 & B. Reid & $42^{\circ} 58^{\prime}, 146^{\circ} 46^{\prime}$ & 51377 \\
\hline$-70 \mathrm{~m}$ uphill from the Lenah Valley fire track & $01 / 11 / 2001$ & S. McMullen-Fisher & $42^{\circ} 52^{\prime}, 147^{\circ} 15^{\prime}$ & 519153 \\
\hline
\end{tabular}

${ }^{1}$ Locality descriptions are as they appear on the herbarium sheet.

${ }^{2}$ Specimens from the same site are also held at National Herbarium of Victoria MEL (type specimen) with duplicates at Royal Botanic Gardens, Kew, and Botanischer Garten und Botanisches Museum, Berlin-Dahlem.

${ }^{3}$ Specimens from the same site but held on different herbarium sheets.

${ }^{4}$ The specimen at HO has a date of Dec 1890, but specimens in MEL are dated 16/11/1890. 


\section{Field Surveys}

The catalyst for this study was the incidental discovery of $T$. rodwayi on Archers Sugarloaf near Meander in Tasmania's central north, during an Understorey Network field day (15 October 2002) in an area of State forest proposed for logging. The two specimens found on this occasion were detached flowers lying on the soil surface, apparently after being unearthed by animals. The subsequent survey work focused initially on the general vicinity of this find, both within the proposed logging coupe and other forest sites in the Meander area. Less extensive surveys were carried out later in other regions of the state. Sites and survey methods are described below.

\section{Archers Sugarloaf coupe}

The proposed coupe on Archers Sugarloaf (known as HU302D) is on a gently-sloping bench with a northerly aspect, on Jurassic dolerite and dolerite talus. Vegetation within the coupe graded from wet to dry sclerophyll forest and had a multi-aged structure, including some old-growth trees. Eucalyptus obliqua L'Hérit. is the dominant tree, with E. amygdalina Labill., E. viminalis Labill. and E. delegatensis subsp. tasmaniensis Boland also present. Stumps with shoe marks throughout the area indicated that selective logging had occurred more than 50 years ago, and it is likely that the area was also logged for sleepers in the 1960s.

Two sampling methods were used in coupe HU302D on 9-10 December 2002 to both systematically search a range of habitats and maximise the probability of finding populations of $T$. rodwayi.

Stratified random sampling. In all, 13 sites were sampled across a range of habitats within the coupe. They were spaced $100-400 \mathrm{~m}$ apart using a quadrat-based sampling method. Five $1 \mathrm{~m}^{2}$ quadrats were established at each site, the first quadrat being positioned by random throw, and the subsequent quadrats being located at cardinal points about 5 $\mathrm{m}$ distant from the first quadrat. The leaf litter was removed from within each quadrat, and the soil excavated to a depth of $1-5 \mathrm{~cm}$. Details of the vegetation were recorded at each site, including approximate height and cover of each stratum. For the purposes of the vegetation description, each site was defined as an area of approximately $10 \mathrm{~m}$ radius.

Focused sampling. Seven of the 13 sites sampled using the stratified random approach supported wetter forest types that were apparently favourable $T$. rodwayi habitat (based on the observations from the surveys in HU302D and sites of historical records). These sites were more intensively surveyed using the same scratching and excavation techniques but without the use of quadrats. The additional area searched was estimated for each intensively sampled site. Within each of the intensively surveyed sites, a proportion of ground (up to $50 \%$ ) was clearly not suitable habitat, because of the presence of localised obstacles such as large rocks, logs and the standing trunks of trees and tall shrubs.

A preliminary search conducted within the coupe on 15 November 2002 used similar methods to those adopted for the intensively sampled sites. The data from these initial sites are therefore included as part of this study. The two detached T. rodwayi lowers found incidentally on 15 October 2002 , which instigated this study, are not included in the results presented here because we are not certain that they were actually excavated at these sites. One site, noted for its abundance of $T$. rodwayi flowers during the December survey work, was re-inspected in mid-February 2003.

\section{Wider Meander area}

Thirteen sites on State forest within about $10 \mathrm{~km}$ of the Archers Sugarloaf coupe (HU302D) were sampled on 10-11 December 2002 based on apparent suitability of $T$. rodwayi habitat and physical accessibility. The judgement of habitat suitability was based on observations made during the more systematic sampling of the Archers Sugarloaf (see above). Habitat variables recorded for each site were the same as those used in the Archers Sugarloaf survey. Geology was also recorded in each case. It should be noted that much of the forest in the Meander area has been subject to extensive forestry activities since the $1950 \mathrm{~s}$. However, we did not attempt to stratify the sampling according to logging regime or the forest age.

\section{Additional areas}

It was not possible to conduct a statewide survey for $T$. rodwayi as part of this study. However, we considered it prudent to examine sites of historical records, where locatable, to determine if the species could still be found at these sites. Forest in the approximate location of the site of the 1968 record at the Little Denison River (based on the description of the site on the herbarium specimen sheet) was searched on 18 December 2002. The site of the recent 2002 record from Lenah Valley, near Hobart on the lower slopes of Mount Wellington (Cascades), was searched on 10 January 2003. However, the site of the reliable sighting near Neika on the slopes of Mount Wellington was not searched as information on this site was obtained after the flowering period of the species. The sites of the records of Rodway from Mount Wellington and the Mount Field area were not re-surveyed due to the lack of information on their exact location.

Based on an unconfirmed sighting of the species in the late 1980s (K. Bonham, pers. comm.), an area at the end of New Road, near Franklin, was searched on 18 December 2002, as were several other sites with similar habitat within the vicinity.

\section{Specimen collection}

Specimens were collected from numerous locations under permits issued by the Department of Primary Industries, Water and Environment (DPIWE). Collected specimens were lodged at the Tasmanian Herbarium (HO).

\section{Conservation assessment}

The Conservation Status Assessment Program developed by the Threatened Species Unit (DPIWE 2002) was used to assess the conservation status of $T$. rodwayi in Tasmania. Population size was entered as 'unknown' due to the difficulty in estimating the size of all of the known populations for the species. The distribution of the species was based on both recent and historical records, but not extended to potential habitat where no records exist.

\section{RESULTS}

\section{Distribution of Thismia rodwayi in Tasmania}

The known distribution of T. rodwayi in Tasmania is shown in figure 2 , and all sites are listed in appendix 1 . The species has a disjunct distribution (Meander, Ben Lomond, Mount 
Wellington, Mount Field, Glen Huon and Little Denison River area) and is known from over 20 sites.

\section{Population Details and Habitat Characteristics}

In the following discussion, the term 'flower' is used to describe specimens of $T$. rodwayi recorded in various stages of flowering. In addition, a single 'flower' is equated to an individual plant (because our excavations did not extend to clearing of soil from the delicate root system from which one or more flowers may have arisen).

A total of 110 flowers of $T$. rodwayi were found in the Meander area and a further 12 in the south of the state in the course of this survey. For each general survey area, a summary of observations regarding habitat characteristics and population sizes are given below.

\section{Archers Sugarloaf coupe}

Thismia rodwayi was recorded once only using the stratified random sampling method. However, the focused sampling at sites that represented prospective habitat resulted in $T$. rodwayibeing found at seven sites. The number of individual flowers found within each 'population' ranged from one to
24. A total of 56 flowers was recorded from approximately $150 \mathrm{~m}^{2}$ of ground examined over the 16 sites. Location, general environmental data and number of flowers recorded for all sites searched within the coupe are given in table 2 , and shown in figure 3 . Also marked on figure 3 is the approximate location of five sites (sites a, b, c, d and e) informally searched for Thismia during our preliminary search on 15 November 2002.

All records from the coupe area were from patches of wetter vegetation, not in the dry/damp sclerophyll forest that occupied most of the coupe area. Eucalyptus obliqua was the dominant canopy species throughout the coupe, and Pteridium esculentum (Forst.f.) Cockayne, Coprosma quadrifida (Labill.) Robinson and Pultenaea juniperina Labill. were common in the understorey. Understorey species that were especially prominent where $T$. rodwayi was found included Bedfordia salicina (Labill.) DC., Pomaderris apetala Labill. and Blechnum nudum (Labill.) Mett. ex. Luerss.

No T. rodwayi flowers were found in mid-February during a re-inspection of one site within the Archers Sugarloaf survey area where flowers had been abundant in December (site 8, table 2).

A rough estimate of the number of $T$. rodwayi individuals within the area of the proposed coupe (approximately 100

TABLE 2

Details of sites searched for Thismia rodwayi on Archers Sugarloaf

\begin{tabular}{|c|c|c|c|c|c|c|c|c|c|c|}
\hline Site $^{1}$ & Easting & Northing & $\begin{array}{l}\text { Altitude } \\
\text { (m) }\end{array}$ & $\begin{array}{l}\text { Slope } \\
\left(^{\circ}\right)\end{array}$ & Aspect & Landform & $\begin{array}{c}\text { Rock } \\
\text { cover } \\
(\%)\end{array}$ & Drainage & $\begin{array}{c}\text { Scratched } \\
\left(\mathrm{x} 1 \mathrm{~m}^{2}\right)\end{array}$ & $\begin{array}{c}\text { Number of } \\
\text { Thismia }\end{array}$ \\
\hline \multicolumn{11}{|c|}{ Positive sites } \\
\hline 4 & 468008 & 5386663 & 445 & 2 & $\mathrm{NE}$ & Mid-slope/shelf & $10-20$ & mod-good & 11 & 3 \\
\hline $8^{2}$ & 468500 & 5387020 & 405 & $<2$ & $\mathrm{NE}$ & Mid-slope/shelf & $<2$ & good & 20 & $24\left(\right.$ plus $\left.15^{3}\right)$ \\
\hline 10 & 467597 & 5387160 & 435 & 2 & $\mathrm{~N}$ & Shelf & $<5$ & fair & 15 & 2 \\
\hline 11 & 467759 & 5387242 & 430 & 2 & $\mathrm{~N}$ & Shelf & $<5$ & good & 15 & 1 \\
\hline a & 467940 & 5387408 & 415 & $<5$ & $\mathrm{~N}$ & Mid-slope/shelf & $<5$ & good & 15 & 3 \\
\hline b & 467647 & 5387340 & 425 & 0 & 0 & Shelf & 0 & fair/good & 15 & 5 \\
\hline c & 467621 & 5387245 & 436 & $<2$ & $\mathrm{~N}$ & Shelf & $<5$ & good & 15 & 3 \\
\hline \multicolumn{11}{|c|}{ Negative Sites } \\
\hline 1 & 467628 & 5386771 & 470 & $<5$ & NE & Mid-slope & 5 & good & 5 & 0 \\
\hline 2 & 467713 & 5386834 & 455 & $<5$ & $\mathrm{NE}$ & Mid-slope & $<5$ & good & 5 & 0 \\
\hline 3 & 467814 & 5386795 & 455 & $<5$ & $\mathrm{NE}$ & Mid-slope & 5 & good & 5 & 0 \\
\hline 5 & 468166 & 5386516 & 440 & 5 & $\mathrm{NE}$ & Mid-siope & 5 & good & 5 & 0 \\
\hline 6 & 468319 & 5386449 & 425 & 5 & $\mathrm{E}$ & $\begin{array}{l}\text { Drainage } \\
\text { depression }\end{array}$ & 5 & fair & 5 & 0 \\
\hline 7 & 468609 & 5386594 & 405 & $<5$ & $\mathrm{E}$ & Mid-slope & $30-40$ & good & 5 & 0 \\
\hline 9 & 467507 & 5387108 & 405 & 0 & & Shelf & 5 & good & 5 & 0 \\
\hline 12 & 467833 & 5387111 & 437 & 3 & NNE & Shelf & 30 & good & 5 & 0 \\
\hline 13 & 468209 & 5386901 & 425 & 1 & $\mathrm{NE}$ & Shelf & 0 & fair & 5 & 0 \\
\hline
\end{tabular}

1 Sites 1-13 were surveyed on 9-10 December 2002. Sites a, b and $\mathrm{c}$ were surveyed during a preliminary search on 15 November 2002.

2 One flower was found using the quadrat sampling method at this site.

${ }^{3}$ These additional 15 flowers were about $20 \mathrm{~m}$ north of the formally sampled and described site, but were too close to be considered an additional site. Pomaderris apetala rather than Olearia argophylla was locally dominant; however, the site was otherwise very similar. 


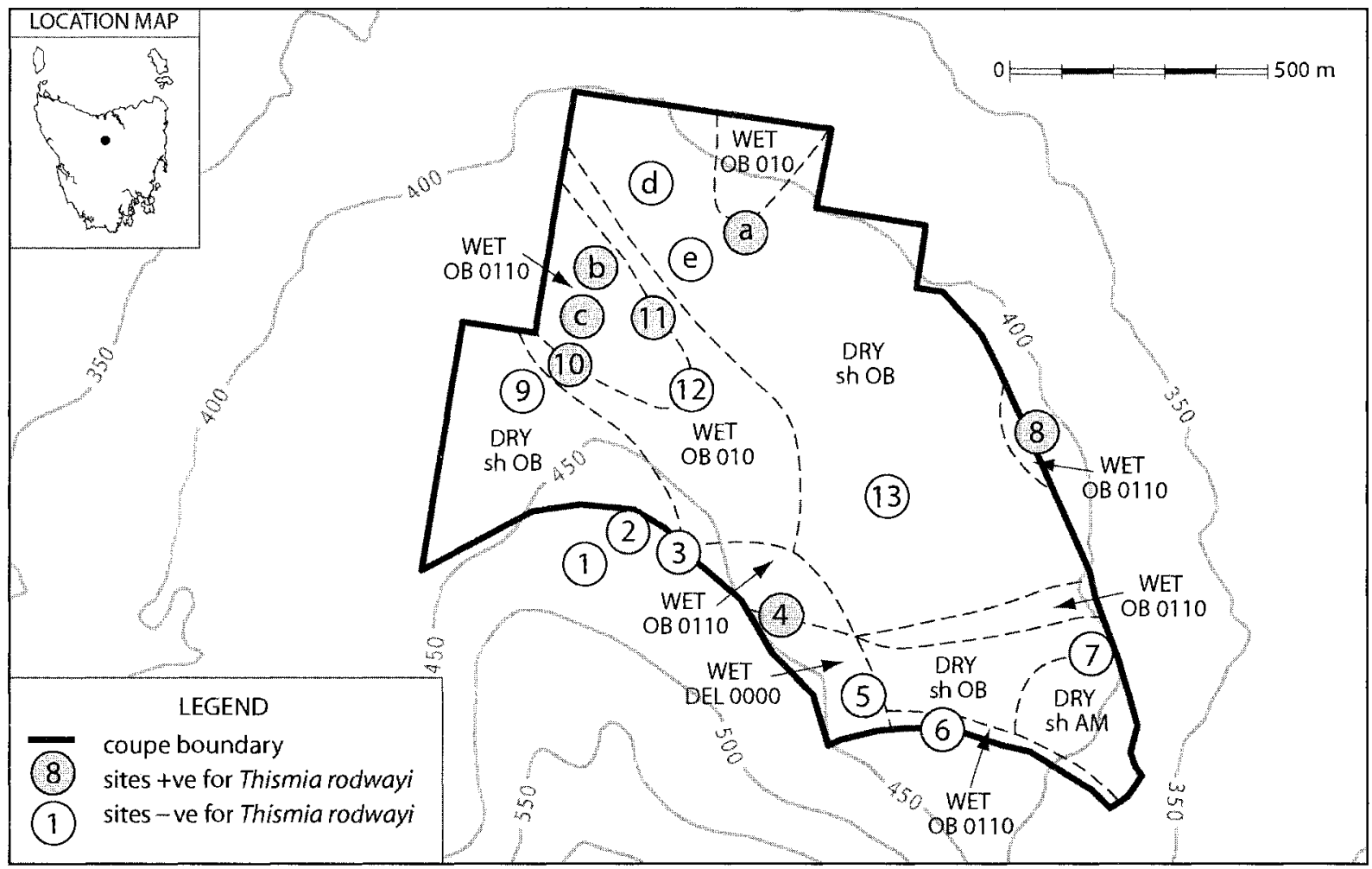

FIG. 3- Coupe HU302D with sites searched for Thismia rodwayi and forest communities shown (forest community nomenclature follows that of North et al. (1998)). The forest communities as mapped may contain localised areas of other communities. Numbers and letters refer to sample sites (see table 2 and text).

ha) can be made from the density of plants within searched areas, and the extent of suitable habitat. The apparently suitable forest types occupied about 30 ha. A conservative assessment suggests that obstructions such as logs, rocks and other vegetation prevent about half this area being occupied by $T$. rodwayi, thus the potential habitat is reduced to 15 ha. The total area intensively surveyed in these wetter forests was $151 \mathrm{~m}^{2}$ (over 16 sites), uncovering 56 flowers. If the species were to occupy the estimated 15 ha of potential habitat at the same density as in surveyed areas, the total population would be about 70000 .

\section{Wider Meander area}

Thismia rodwayi was found at seven of the 13 sites searched within the wider Meander area (table 3 and fig. 4). All sites surveyed were in wet sclerophyll forest and were mainly on dolerite or dolerite talus, the most extensive substrate in the Meander area. The total number of T. rodwayi flowers found in this area was 54 . The total area searched was approximately $114 \mathrm{~m}^{2}$ (average of $8.8 \mathrm{~m}^{2}$; range of $7-27 \mathrm{~m}^{2}$ ).

\section{Additional areas}

Thismia rodwayi was not found in the Little Denison River area. The current habitat in this site appeared dry (very low moisture in leaf litter) compared to sites supporting the species in the Archers Sugarloaf/Meander area. The geology was Permian mudstone.

The species was not found at the Lenah Valley site (where it had been found in late spring 2002) when it was searched in January 2003. The leaf litter and soil were very dry following atypically dry conditions in southeastern Tasmania for the preceding three months. The vegetation was very similar to other T. rodwayi sites, with a dense tall shrub layer of P. apetala and Olearia argophylla (Labill.) Benth. below a eucalypt canopy dominated by Eucalyptus regnans F.Muell. and E. obliqua. This site was on Permian mudstone.

Seven flowers of T. rodwayi were found at the end of New Road, near Franklin (Glen Huon area), at about the same location as the anecdotal sighting by $\mathrm{K}$. Bonham in the late 1980 s (table 4). Five of these were in a single clump, and two were located about $100 \mathrm{~m}$ distant within about $10 \mathrm{~m}$ of each other. These plants were situated on a west-facing slope on Jurassic dolerite. The dominant canopy tree was $E$. delegatensis. Atherosperma moschatum Labill., P. apetala and $B$. salicina formed a thick tall shrub layer. Blechnum wattsii Tind. was common but only locally dense.

Five flowers of T. rodwayi, in a single clump, were recorded at Blue Gum Hill, about $4.5 \mathrm{~km}$ from the above-mentioned site, and also on Jurassic dolerite (table 4). This site was dominated by E. regnans regrowth (approximately $30-40$ years old) with a 5-15 m tall understorey of Pomaderris apetala, Olearia argophylla and Acacia melanoxylon and a moderately dense fern layer (mostly Polystichum proliferum).

\section{General Observations}

Thismia rodwayi was found in various stages of flowering, from small buds to senescent flowers and early stages of fruit formation. Flowers in different stages of development were often found at the same site. Flowers occurred in a humus layer where fungal hyphae were prominent at the interface between soil and leaflitter and occasionally just below the soil surface. Leaf litter covered them in all cases and was typically 
TABLE 3

Sites searched for Thismia rodwayi in the Meander area, excluding Archers Sugarloaf

\begin{tabular}{|c|c|c|c|c|c|c|c|c|c|c|c|}
\hline $\begin{array}{l}\text { Location or coupe } \\
\text { name }\end{array}$ & $\begin{array}{l}\text { East- } \\
\text { ing }\end{array}$ & $\begin{array}{l}\text { North- } \\
\text { ing }\end{array}$ & $\begin{array}{l}\text { Altitude } \\
\text { (m) }\end{array}$ & $\begin{array}{c}\text { Slope } \\
\left({ }^{\circ}\right)\end{array}$ & Aspect & Landform & Geology & $\begin{array}{c}\text { Rock } \\
\text { cover } \\
(\%)\end{array}$ & $\begin{array}{l}\text { Drain- } \\
\text { age }\end{array}$ & $\begin{array}{l}\text { Scratched } \\
\left(\mathrm{m}^{2}\right)\end{array}$ & $\begin{array}{c}\text { Number } \\
\text { of } \\
\text { Thismia }\end{array}$ \\
\hline \multicolumn{12}{|l|}{ Positive sites } \\
\hline Warners Sugarloaf & 470277 & 5386284 & 450 & $<5$ & NW & Mid-slope & Dolerite & $<5$ & good & 5 & 5 \\
\hline $\begin{array}{l}\text { East of Meander } \\
\text { River }\end{array}$ & 462859 & 5380724 & 610 & 10 & $\mathrm{~N}$ & $\begin{array}{l}\text { Drainage } \\
\text { depression }\end{array}$ & $\begin{array}{l}\text { Dolerite } \\
\text { talus }\end{array}$ & 5 & $\begin{array}{l}\text { fair- } \\
\text { good }\end{array}$ & 8 & 7 \\
\hline Jackeys Creek FR ${ }^{1}$ & 470474 & 5386494 & 440 & $\begin{array}{l}20 \\
25\end{array}$ & SE & $\begin{array}{l}\text { Slope near } \\
\text { river }\end{array}$ & Dolerite & $<3$ & good & 10 & 13 \\
\hline Warners Sugarloaf & 469875 & 5385927 & 435 & 1 & W & Mid-slope & Dolerite & $<5$ & good & 7 & 3 \\
\hline $\begin{array}{l}\text { Meander River } \\
\text { SSR }\end{array}$ & 463447 & 5381741 & 510 & 20 & $\mathrm{~N}$ & Gully & $\begin{array}{l}\text { Dolerite } \\
\text { talus }\end{array}$ & $5-10$ & $\begin{array}{l}\text { fair- } \\
\text { good }\end{array}$ & $25-30$ & 5 \\
\hline $\begin{array}{l}\text { Meander River } \\
\text { SSR }\end{array}$ & 461997 & 5380691 & 590 & 3 & $\mathrm{~N}$ & $\begin{array}{l}\text { Drainage } \\
\text { depression }\end{array}$ & $\begin{array}{l}\text { Dolerite } \\
\text { talus }\end{array}$ & 5 & $\begin{array}{l}\text { fair- } \\
\text { good }\end{array}$ & $20-25$ & 18 \\
\hline $\begin{array}{l}\text { Meander River } \\
\text { SSR }\end{array}$ & 463980 & 5382231 & 465 & $1-3$ & $\mathrm{~N}$ & $\begin{array}{l}\text { Riparian } \\
\text { flats }\end{array}$ & $\begin{array}{l}\text { Dolerite } \\
\text { talus }\end{array}$ & $<1$ & fair & $10-12$ & 3 \\
\hline \multicolumn{12}{|l|}{ Negative sites } \\
\hline Warners Sugarloaf & 470222 & 5386288 & 450 & 5 & NW & Mid-slope & Dolerite & $<5$ & good & 25 & 0 \\
\hline Smoko Rd & 462752 & 5383020 & 570 & $\begin{array}{c}25- \\
30\end{array}$ & $S$ & Mid-slope & $\begin{array}{l}\text { Permian } \\
\text { mudstone }\end{array}$ & $<3$ & good & 20 & 0 \\
\hline Smoko Rd & 462084 & 5383300 & 600 & $\begin{array}{c}25- \\
30\end{array}$ & $S$ & Mid-slope & $\begin{array}{l}\text { Permian } \\
\text { mudstone }\end{array}$ & $<5$ & good & 15 & 0 \\
\hline Smoko Creek SSR & 463828 & 5382583 & 470 & 0 & & $\begin{array}{l}\text { Riparian } \\
\text { flats }\end{array}$ & $\begin{array}{l}\text { Permian } \\
\text { mudstone }\end{array}$ & $<2$ & $\begin{array}{l}\text { poor- } \\
\text { fair }\end{array}$ & 17 & 0 \\
\hline $\begin{array}{l}\text { Meander River } \\
\text { SSR }\end{array}$ & 465160 & 5382723 & 435 & 0 & $\mathrm{NE}$ & $\begin{array}{l}\text { Riparian } \\
\text { flats }\end{array}$ & $\begin{array}{l}\text { Dolerite } \\
\text { talus }\end{array}$ & $<5$ & fair & 10 & 0 \\
\hline Meander FR & 461983 & 5380679 & 600 & 15 & $\mathrm{E}$ & Mid-slope & $\begin{array}{l}\text { Permian } \\
\text { mudstone }\end{array}$ & $7-10$ & good & 7 & 0 \\
\hline
\end{tabular}

${ }^{1}$ Abbreviations used: SSR $=$ streamside reserve; FR $=$ Forest Reserve. All sites are in State forest.

$2-4 \mathrm{~cm}$ thick. The composition of the leaf litter was variable but broad-leaved understorey species such as B. salicina and $P$ apetala were the main components.

Flowers of $T$. rodwayi were borne on a short vertical white stalk, less than $5 \mathrm{~cm}$ long, attached at right angles to a vermiform white root, about $5-15 \mathrm{~cm}$ long. Generally there was only one flower per plant, although one specimen was found with two flowers, each on a separate stalk attached to the same root.

Flowers (putatively representing individuals) were commonly found in groups of 2-5 (although sometimes up to 12) across an area of less than $1 \mathrm{~m}^{2}$. Several such clumps were observed at the sites where the species was most abundant. These clumps were sometimes close enough to appear as one large clump (i.e., less than about $2 \mathrm{~m}$ apart) or were seemingly 'connected' by one or two flowers spaced between them.

It is difficult to determine whether all individuals within the surveyed area on Archers Sugarloaf are part of a single population, or whether they belong to a number of small isolated populations, separated by drier forest. This is due to the paucity of knowledge of the pollination and distribution mechanisms of this species. While information on this aspect of the species' biology remains lacking, estimates of functional population size and extent can only be tentative (see discussion below).

\section{DISCUSSION}

\section{Distribution and Ecology of Thismia rodwayi}

In 1890, Baron von Mueller made the following comments about T. rodwayi: “... that so remarkable, and to some extent also showy plant should have evaded hitherto observation, although since almost nearly 100 years the region about the estuary of the Derwent has been searched for plants, finds perhaps its explanation in the fact, that in all likelihood the flower only is peeping above the soil between decaying foliage, and thus might be easily taken for a young Aseroe or some other fungus ... furthermore, each flower must be very ephemerous and perishable ... now it will likely be found in other places of the island, perhaps, also, in New Zealand and in Continental Australia" (von Mueller 1890a: 233).

The baron was right in all aspects of his somewhat flowery statement: the species has indeed been found elsewhere in Tasmania, New Zealand and mainland Australia. In Tasmania, T. rodwayi is now known from several disjunct sites including recent records in the Meander area, an uncurated but reliable record from the northeast of the State, historical records from the Mount Field area, and recent and historical records from the Mount Wellington, Glen Huon and Little Denison River areas (fig. 2; Appendix 1). 


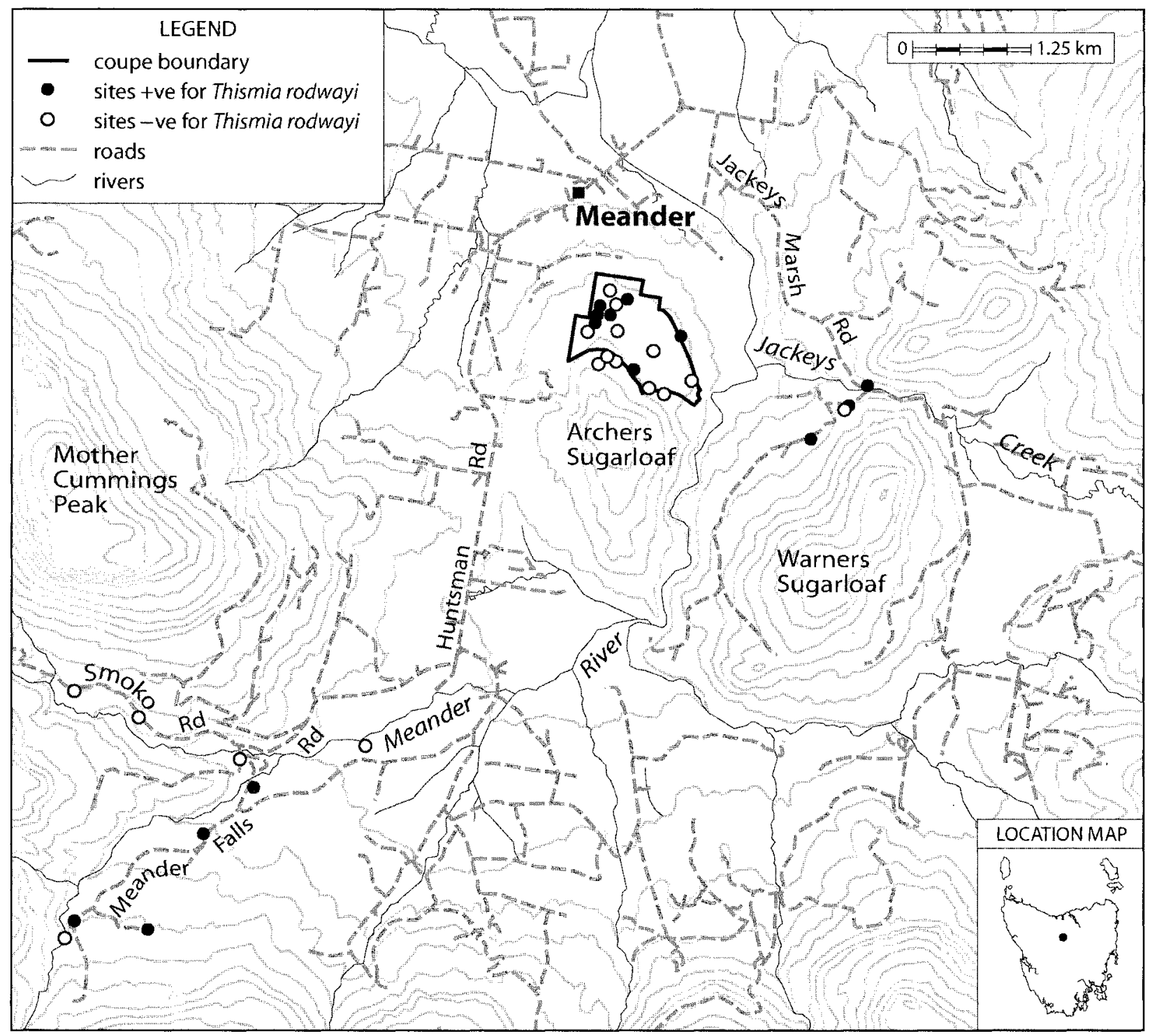

FIG. 4 - The Meander area, showing sites searched for Thismia rodwayi.

TABLE 4

Additional sites from the south of the state where Thismia rodwayi was recorded

\begin{tabular}{|c|c|c|c|c|c|c|c|c|c|c|c|}
\hline Location & Easting & Northing & $\begin{array}{c}\text { Altitude } \\
\text { (m) }\end{array}$ & $\begin{array}{l}\text { Slope } \\
\left(^{\circ}\right)\end{array}$ & Aspect & Landform & Geology & $\begin{array}{l}\text { Rock } \\
\text { cover } \\
(\%)\end{array}$ & Drainage & $\begin{array}{c}\text { Scratched } \\
\left(\mathrm{m}^{2}\right)\end{array}$ & $\begin{array}{c}\text { Number of } \\
\text { Thismia }\end{array}$ \\
\hline $\begin{array}{l}\text { New Rd, } \\
\text { Franklin }\end{array}$ & 495197 & 5230445 & 435 & $5-10$ & W & midslope & Dolerite & $5-10$ & good & 10 & 5 \\
\hline $\begin{array}{l}\text { New Rd, } \\
\text { Franklin }\end{array}$ & 495195 & 5230252 & 440 & 10 & W & midslope & Dolerite & 20 & good & 10 & 2 \\
\hline $\begin{array}{l}\text { Blue Gum } \\
\text { Hill, near } \\
\text { Glen Huon }\end{array}$ & 491200 & 5232900 & 470 & 10 & SW & midslope & Dolerite & $10-20$ & good & 15 & 5 \\
\hline
\end{tabular}


The present study extends the distribution of the species to include the northern part of the Midlands floristic region (as defined by Orchard 1988).

Von Mueller originally mused "... whether it lives exclusively on the roots of the Musk-Aster, or whether it is nourished also by the roots of any other plants ..." but continued in the same manuscript that "... he [Mr Rodway] noticed the plant to grow also on the roots of Bedfordia..." (von Mueller 1890a: 233, 235). Tasmanian site records, and information from the present study, suggest that $T$. rodwayi is strongly associated with wet sclerophyll forest (E. obliqua, E. regnans, E. delegatensis or E. viminalis) with an understorey dominated by any or all of $P$ apetala, $O$. argophylla, B. salicina or Acacia melanoxylon (often most of these species are present). In Victoria, the species appears to occur in wetter forest types associated with $O$. argophylla and Bedfordia arborescens Hochr. (N. Walsh, pers. comm.). Although E. obliqua was commonly the dominant eucalypt around Meander, the occurrence of T. rodwayi at some sites with $E$. delegatensis, E. regnans and E. viminalis occurring as dominants or co-dominants suggests eucalypt species may not be a relevant factor in defining suitable habitat. The presence of Thismia in the Archers Sugarloaf coupe was strongly associated with the presence of Blechnum nudum. However, this was not the case in other areas, especially the wetter forest types sampled near the Meander River and at New Road near Franklin, which had a relatively sparse ground fern layer. The Archers Sugarloaf coupe is at the drier end of the habitat spectrum of $T$. rodwayi, and it seems likely that in this forest type $B$. nudum is indicative of wetter sites such as soaks and springs and therefore more suitable T. rodwayi habitat. Ground ferns may also help to create a suitable microhabitat when a dense shrub layer is lacking, although $T$. rodwayi was rarely recorded within very dense patches of $B$. nudum.

We had a surprisingly high success rate in recording $T$. rodwayi, considering the cryptic nature of the species. Rodway, when supplying additional specimens to von Mueller in 1890, wrote: "Herewith the result of a whole days search. One flower, one bud and pieces of rhizome ...". It is premature, however, to assume that the species has an extensive distribution through Tasmanian wet sclerophyll forests, as forest type may only be a crude indicator of suitable habitat for $T$. rodwayi. Forests with these characteristics appear to be far more widespread and common than $T$. rodwayi, which suggests that other more specific habitat factors or dispersal ability are the controlling factors for its distribution. A similar situation occurs in Victoria, with apparently suitable habitat being much more common than records of the species ( $\mathrm{N}$. Walsh, pers. comm.).

Thismia rodwayi has been encountered very infrequently since its original collection in 1890 , despite an extensive botanical collecting history in Tasmania (Buchanan 1988), and numerous botanical surveys of Tasmania in recent decades (e.g., Kirkpatrick et al. 1988, North et al. 1998, and numerous (mainly unpublished) surveys of wet forest areas across a range of tenures). We feel that the current range of the species will not be much expanded without intensive surveys, although we consider that it is likely to be more widespread in Tasmania's wetter forests than current records suggest. The species is distinctive, but by no means obvious, and is likely to continue to be unrecorded in routine botanical surveys. The most likely source of new records for T. rodwayi will be from either targeted surveys or from chance encounters by leaf litter researchers. Of the several scientists working on leaf litter species (mostly invertebrates) who were contacted regarding $T$. rodwayi during this study, only one responded with a possible sighting. The lack of chance encounters by researchers who frequently search suitable habitat suggests that the species may be very patchy in its distribution, or that the plants are geographically transient. This latter supposition is supported by Victorian observations in which the species has not been recorded every year from the same known site (N. Walsh, pers. comm.). Von Mueller pointed to the difficulty in finding specimens of this species suggesting that "each flower must be very ephemerous and perishable, and falls probably also quickly to the prey of various insects ..." (von Mueller 1890a: 233).

Leaf litter composition and thickness are likely to be important habitat variables for $T$. rodwayi, given its saprophytic means of nutrition. The composition of the leaf litter on sites supporting the species varied but the moisture content and thickness seemed fairly consistent. The upper layer of leaves was sometimes quite dry but the layer just above the soil was typically damp, dense and cohesive.

Soil and geology are also potentially limiting factors for $T$. rodwayi. The soil where the species was found was generally loamy clay, ranging from quite friable to dense and compacted. Dolerite (or dolerite talus) was the underlying geology of most sites, but this may simply reflect the intensive sampling in the Meander area, which is largely underlain by Jurassic dolerite. The Little Denison River site and Lenah Valley site (table 1) are both on Permian mudstone, suggesting that geology may not be a crucial habitat factor. This is further supported by the knowledge that the species occurs in New Zealand and mainland Australian states, where there is little or no Jurassic dolerite.

The two re-inspections of known $T$. rodwayi sites in January and February, together with historical records, indicate the likely flowering period of the species in Tasmania is October to December. It is possible that the exceptionally dry conditions experienced statewide in January and February 2003 shortened the flowering period for Thismia in this year. It is also possible that the flowering of Thismia in the summer of 2002-2003 was influenced, perhaps even triggered, by the atypically high rainfall of the previous summer. The timing and duration of flowering, and the effect of seasonal variations in climatic factors such as the amount of rainfall, clearly require further study.

The pollination mechanism of $T$. rodwayi remains poorly understood. Possible pollinators include invertebrates, mammals and lizards. The reproductive biology of other species of Thismia is also specularive. Thiele \& Jordan (2002) suggest the flower structure of T. rodwayi and T. clavarioides resembles that of orchids pollinated by fungus gnats, and that an insect pollinator may be constrained once inside the flower, and be forced to leave via the gaps between anther filaments. An animal vector is a possible means of seed dispersal. Mammals such as the potoroo (Potorous tridactylus Kerr) are known to feed on orchid tubers and subterranean fungi in similar forest habitats (Claridge et al. 1992) and may act as vectors for Thismia. Whether other animals may be involved is a matter of conjecture but it is interesting to note that the forest floor in the Glen Huon area (near the southern Tasmanian records of $T$. rodwayz) is extensively disturbed by non-indigenous lyrebirds, Menura novaehollandiae Latham (F. Duncan, pers. obs.).

There are clearly many aspects of the reproductive biology of Thismia that require further research. However, the 
above comments suggest that pollen is transported only short distances (less than $1 \mathrm{~km}$, possibly only metres), and seeds are also dispersed locally. The subterranean flowering and fruiting of Thismia may provide serious limitations to cross-pollination and seed dispersal and hence prevent the species from occupying its climatic and habitat potential. In this case, localised populations would be expected, rather than a widespread distribution in suitable wet forest habitat. At any rate, its clumped distribution indicates that the species has very limited ability to disperse seed or reproductive structures.

\section{Response to disturbance}

Despite limited records of Thismia rodwayi in Tasmania, it is possible to speculate on its response to disturbance. Most records in the Meander area are from either selectively logged forests (in the 1950s, 1960s and 1980s) or from forests subject to more intensive forestry activities such as clearfelling and regeneration burns (at least one site was clearfelled in 1985). Almost all sites in the present study have been burnt at some stage, including the clearfelled sites. Some of the Meander sites may have been protected from high intensity fires associated with forestry regeneration burns or wildfires, as they were on the edge of coupes or in protected gullies. However, sites in the Glen Huon area and on the lower slopes of Mount Wellington were subject to severe wildfires in 1967, and now support regrowth wet sclerophyll forest.

We suggest that maintenance of populations of $T$. rodwayi can be compatible with typical native forest silviculture practised in Tasmanian wet eucalypt forests. However, further evidence from more sites subject to different practices in native forest, and from before-after disturbance event comparisons, would be needed before firm conclusions can be drawn. We consider that $T$. rodwayi would be adversely affected by conversion of wet eucalypt forest to plantation because of the dramatic, and often permanent, changes in site characteristics. Such conversion has occurred extensively in areas with the potential to support $T$. rodwayi (including the base of the Western Tiers, upper Derwent Valley and Ftanklin area). General observations of many intensively managed forestry sites indicate that a dense broad-leaved shrub understorey and suitable litter layer may not develop in a typical rotation period or under typical plantation management practices.

\section{Reservation Status}

Thismia rodwayi is now known from 23 sites in Tasmania (including historical sites cited in this paper); most sites are on public land. The exact location of Rodway's 1890 site is not known but is likely to be on public land that is now part of Wellington Park. Four of the records on public land are located in gazetted reserves (Jackeys Creek Forest Reserve, Wellington Park, Mount Field National Park). A further four are protected by management prescriptions, such as streamside reserves applied under the Forest Practices Code (Anon 2000), or other areas excluded from forestry operations under Forestry Tasmania's Management Decision Classification (MDC) system (Orr \& Gerrand 1998). Eleven records are on unreserved State forest; seven of these are in, or adjacent to, a single coupe on Archers Sugarloaf, and probably represent one or two populations. Most of these sites will also be excluded from forestry operations, and most are candidates for informal reservation through the MDC system.

\section{Conservation Status}

As noted, Thismia rodwayi is listed on Schedule 5 (Rare) of the Tasmanian Threatened Species Protection Act 1995. Considering that the species was known from only three records when the Act was promulgated, and that few population data were available, a listing that reflected a higher level of threat was probably warranted. The additional distribution and population data provided by this study allow the conservation status of the species to be assessed using the Threatened Species Unit's Conservation Status Assessment Program. However, there is still a lack of data concerning population stability and potential threats. The fact that $T$. rodwayi has now been found in areas known to have been disturbed by fire, clearfelling or selective logging (and in some cases both fire and logging) in the past 50 years suggests these are not highly threatening processes. The suitability of areas managed as native forest through successive totations is not known. In the absence of further data concerning threats, $T$. rodwayi cannot be confidently listed as either endangered or vulnerable (guidelines for listing: DPIWE 2002). However, the small number, extent and size of known populations suggest a stochastic risk, and it fulfils three of the category ' $B$ ' criteria for listing as a rare species (table 5, DPIWE 2002). The species may also fit into category 'A' (DPIWE 2002) on the grounds of populations being small and localised, though this category only applies when an ongoing process is known to be pushing the species into a higher extinction risk category.

It is clear from the comments in table 5 that the species satisfies criteria for being listed as 'rare' based on very conservative estimates of population size and extent. The unconfirmed record from the Ben Lomond region has not been included in this assessment, but this single record would not prevent its qualification as rare under criterion B. There is a high likelihood that more populations exist because the typical habitat of the species is widespread and common in Tasmania. However, the crypric nature of the species necessitates a precautionary approach. Long-term monitoring of population size and distribution is likely to be logistically difficult for this species, but such work would provide valuable data on potential threatening processes, such as conversion of wet eucalypt forests to plantation or other land use.

\section{ACKNOWLEDGEMENTS}

This study has been conducted with the financial and technical support of Forestry Tasmania and the Forest Practices Board. Bob Hamilton and Henry Chan from Forestry Tasmania (Mersey District) gave field assistance, as did Mick Brown, Sandy Tiffin, Kevin Knowles, Kevin Bonham, Greg Jordan and Chris Harwood. Wendy Potts (Threatened Species Unit, DPIWE) performed the analysis of conservation status. Alex Buchanan (Tasmanian Herbarium, HO) provided historical information and Andrew Wilson (Forestry Tasmania) assisted the authors to obtain relevant literature. Neville Walsh (Royal Botanic Gardens, Melbourne) provided information on records in their herbarium (MEL) and interesting discussion on the species. Ross Jones provided information on 
TABLE 5

The criteria for 'rare' (Schedule 5) satisfied by Thismia rodwayi

\begin{tabular}{|c|c|}
\hline Criteria $^{1}$ & Comments \\
\hline B. Extent of occurrence $<2000 \mathrm{sq} \mathrm{km}$ & $\begin{array}{l}\text { Extends from the Meander area in the central north, to Mt Field in the central south } \\
\text { (about } 120 \mathrm{~km} \text { ), southeast to the Glen Huon area (about } 50 \mathrm{~km} \text { ), and to the Hobart } \\
\text { area (about } 40 \mathrm{~km} \text { ). The total extent of occurrence is approximately } 670 \mathrm{sq} \mathrm{km} \text {. }\end{array}$ \\
\hline B. Area of occupancy $<50$ ha & $\begin{array}{l}\text { The clumped and patchy distribution of Thismia suggests that the actual area } \\
\text { occupied by the species at each site is small, even when clumps are spread out. It is } \\
\text { therefore unlikely that it occupies even a single hectare at each site. The total area of } \\
\text { occupancy is estimated to be less than } 20 \text { ha. }\end{array}$ \\
\hline $\begin{array}{l}\text { B. Most mature individuals in }<10 \\
\text { populations }\end{array}$ & $\begin{array}{l}\text { If a record of Thismia is considered a distinct population when more than } 500 \mathrm{~m} \\
\text { from any other record and suitable habitat is not continuous, } 90 \% \text { of individuals } \\
\text { occur in just four populations (all in the Meander area). }\end{array}$ \\
\hline
\end{tabular}

${ }^{1}$ The criteria are taken from a pamphlet produce by the Threatened Species Unit (DPIWE 2002).

the Neika site. The maps were created with the assistance of Gerald Coombe (Forestry Tasmania) and the photo was taken by Hans and Annie Wapstra. Two referees provided useful comments on the manuscript.

\section{REFERENCES}

Anon., 2000: Forest Practices Code. Forest Practices Board, Hobart.

Buchanan, A. M., 1988: The Tasmanian Collecting Localities of Ronald Gunn and Joseph Milligan. Tasmanian Herbarium Occasional Publication No. 1, Tasmanian Museum and Art Gallery, Hobart.

CAMpbell, E. O., 1968: An investigation of Thismia rodwayi $\mathrm{F}$. Muell. And its associated fungus. Transactions of the Royal Society of New Zealand 3 (14): 209-219.

CCRPL, 2002: Clarence Catchment Rare Plant List (accessed 23 December 2002) <http://www.nor.com.au/environment/ clarencecatchment/vegetation/rares/rarelist.htm $>$.

Claridge, A. W., Tanton, M. T., Seebeck, J. H., Cork, S.J. \& Cunningham, R.B., 1992: Establishment of ectomycorrhizae on the roots of two species of Eucalyptus from fungal spores contained in the faeces of the long-nosed potoroo (Potorous tridactylus). Australian Journal of Ecology 17: 207-17.

Coleman, D. G., 1936: Sarcosiphon rodwayi in Australia. The Victorian Naturalist 52: 163-166.

Coleman, D. G., 1941: Further notes on "fairy lanterns". The Victorian Naturalist 57: 167-168.

Conn, B. J., 1994: Burmanniaceae. In Walsh, N. G. \& Entwisle, T. J. (Eds): Flora of Victoria. Volume 2. Inkata Press, Melbourne.

CribB, A. B., 1995: The saprophytic flowering plant, Thismia yorkensis sp. nov., from Australia. Queensland Naturalist $33(3-4): 51-56$.

Curtis, W. M. \& Morris, D. I., 1994: The Student's Flora of Tasmania Part $4 b$ Angiospermae: Alismataceae to Burmanniaceae. St David's Park Publishing, Hobart.
DPIWE, 2002: Guidelines for the Listing of Species Under the Tasmanian Threatened Species Protection Act 1995. Information brochure produced by the Department of Primary Industries, Water and Environment, Tasmania.

JONKER, F. P., 1938: A monograph of the Burmanniaceae. Mededeelingen van het Botanisch Museum en Herbarium van de Rijks Universiteit te Utrecht 51: 1-279.

Kirkpatrick, J. B., Peacock, R. J., Culien, P. J. \& Neyland, M. G., 1988: The Wet Eucalypt Forests of Tasmania. Tasmanian Conservation Trust Inc., Hobart.

MoClennan, E. L., 1958: Thismia rodwayi F. Muell. and its endophyte. Australian Journal of Botany 6: 25-37.

Moore, L. B. \& EDGAR, E., 1976: Flora of New Zealand Volume II. Government Printer, Weilington.

North, A., Johnson, K., Zlegler, K., Duncan, F., Hopkins, K., ZIEGELER, D. \& WATTS, S., 1998: Flora of Recommended Areas for Protection and Forest Reserves in Tasmania. Forest Practices Board, Forestry Tasmania, and Parks and Wildlife Service, Tasmania.

OrChard, A.E., 1988: A natural regions map for Tasmania. Papers and Proceedings of the Royal Society of Tasmania 122 (2): 47-51.

OrR, S. \& Gerrand, A.M., 1998: Management Decision Classification: a system for zoning land managed by Forestry Tasmania. Tasforests 10: 1-14.

RoDway, L., 1903. The Tasmanian Flora. Government Printer, Hobart.

Thiele, K. R. \& Jordan, P., 2002: Thismia clavarioides (Thismiaceae), a new species of Fairy Lantern from New South Wales. Telopea 9(4): 765-771.

Von Mueller, F, 1890a: Notes on a new Tasmanian plant of the order Burmanniaceae. Proceedings of the Royal Society of Tasmania 1890-1891: 232-235.

Von Mueller, F., 1890b: Descriptions of new Australian plants, with othet annotations. The Victorian Naturalist 8: $114-116$

Willis, J. H., 1970: A Handbook to Plants in Victoria Volume I: Ferns, Conifers and Monocotyledons. Melbourne University Press, Carlton, Victoria.

(accepted 29 September 2003) 
APPENDIX 1

Register of all known Thismia rodwayi sites from Tasmania (including records from this study, DPIWE's GTSpot database and Tasmanian Herbarium (HO) records)

\begin{tabular}{|c|c|c|c|c|c|c|c|c|c|}
\hline Date & Site $^{1}$ & Recorder $^{2}$ & $\begin{array}{l}\text { Easting - Northing }{ }^{3} \\
\text { Latitude - Longitude }\end{array}$ & $\begin{array}{l}\text { Altitude } \\
\text { (m) }\end{array}$ & Geology & Forest type ${ }^{5}$ & No. & HO no. & $\begin{array}{l}\text { Preci- } \\
\text { sion }^{6}\end{array}$ \\
\hline Dec. $1890^{9}$ & Cascades, Hobart ${ }^{?}$ & L. Rodway & $\begin{array}{l}523800 \mathrm{mE} 5249300 \mathrm{mN} \\
42^{\circ} 54^{\prime} \mathrm{S} 147^{\circ} 17^{\prime} \mathrm{E}\end{array}$ & 290 & & & & 25468 & 2 \\
\hline Nov, 1923 & $\begin{array}{l}\text { Mt Field Track } \\
\text { (Mt Dobson Rd) }\end{array}$ & L. Rodway & $\begin{array}{l}476100 \mathrm{mE} 5273400 \mathrm{mN} \\
42^{\circ} 41^{\prime} \mathrm{S} 146^{\circ} 42^{\prime} \mathrm{E}\end{array}$ & 300 & & & & 23812 & 2 \\
\hline 1968 & $\begin{array}{l}\text { Link Road between } \\
\text { Russell River Road and } \\
\text { Little Denison River }\end{array}$ & B. Reid & $\begin{array}{l}481700 \mathrm{mE} 5241900 \mathrm{mN} \\
42^{\circ} 58^{\prime} \mathrm{S} 146^{\circ} 46^{\prime} \mathrm{E}\end{array}$ & 120 & & & & 115634 & 2 \\
\hline $20 / 10 / 68$ & $\begin{array}{l}\text { Little Denison River } \\
\text { via Judbury }{ }^{8}\end{array}$ & $\begin{array}{l}\text { B. Reid \& W.M. } \\
\text { Curtis }\end{array}$ & $\begin{array}{l}481700 \mathrm{mE} 5241900 \mathrm{mN} \\
42^{\circ} 58^{\prime} \mathrm{S} 146^{\circ} 46^{\prime} \mathrm{E}\end{array}$ & 120 & & & & 51377 & 2 \\
\hline ?1980s & Ben Lomond region ${ }^{10}$ & Unknown & $560000 \mathrm{mE} 5420000 \mathrm{mN}$ & & & & & & 5 \\
\hline$? 1980 \mathrm{~s}$ & Neika area & R. Jones & $518750 \mathrm{mE} 5244700 \mathrm{mN}$ & 400 & & & & & 1 \\
\hline $01 / 11 / 02$ & Lenah Valley fire track & S. McMullen-Fisher & $\begin{array}{l}521350 \mathrm{mE} 5352150 \mathrm{mN} \\
42^{\circ} 52^{\prime} \mathrm{S} 147^{\circ} 15^{\prime} \mathrm{E}\end{array}$ & 320 & Dolerite & $\begin{array}{l}\text { WET-REG } \\
1001\end{array}$ & & 519153 & 1 \\
\hline $15 / 11 / 02$ & Archers Sugarloaf & $\begin{array}{l}\text { N. Fitzgerald (this } \\
\text { study) }\end{array}$ & $\begin{array}{l}467940 \mathrm{mE} 5387408 \mathrm{mN} \\
41^{\circ} 39^{\prime} \mathrm{S} 146^{\circ} 36^{\prime} \mathrm{E}\end{array}$ & 415 & Dolerite & $\begin{array}{l}\text { WET- } \\
\text { OB010 }\end{array}$ & 3 & 519512 & 1 \\
\hline $15 / 11 / 02$ & Archers Sugarloaf & $\begin{array}{l}\text { N. Fitzgerald (this } \\
\text { study) }\end{array}$ & $\begin{array}{l}467647 \mathrm{mE} 5387340 \mathrm{mN} \\
41^{\circ} 39^{\prime} \mathrm{S} 146^{\circ} 36^{\prime} \mathrm{E}\end{array}$ & 425 & Dolerite & $\begin{array}{l}\text { WET- } \\
\text { OB0110 }\end{array}$ & 5 & 519510 & 1 \\
\hline $15 / 11 / 02$ & Archers Sugarloaf & $\begin{array}{l}\text { N. Fitzgerald (this } \\
\text { study) }\end{array}$ & $\begin{array}{l}467621 \mathrm{mE} 5387245 \mathrm{mN} \\
41^{\circ} 39^{\prime} \mathrm{S} 146^{\circ} 36^{\prime} \mathrm{E}\end{array}$ & 436 & Dolerite & $\begin{array}{l}\text { WET } \\
\text { OB0110 }\end{array}$ & 3 & 519511 & 1 \\
\hline $09 / 12 / 02$ & Archers Sugarloaf & this study & $468008 \mathrm{mE} 5386663 \mathrm{mN}$ & 445 & Dolerite & $\begin{array}{l}\text { WET } \\
\text { OB0110 }\end{array}$ & 3 & & 1 \\
\hline $09 / 12 / 02$ & Archers Sugarloaf & $\begin{array}{l}\text { F. Duncan (this } \\
\text { study) }\end{array}$ & $\begin{array}{l}468500 \mathrm{mE} 5387020 \mathrm{mN} \\
41^{\circ} 40^{\prime} \mathrm{S} 146^{\circ} 37^{\prime} \mathrm{E}\end{array}$ & 405 & Dolerite & $\begin{array}{l}\text { WET } \\
\text { OB0110 }\end{array}$ & 39 & 521462 & 1 \\
\hline $10 / 12 / 02$ & Archers Sugarloaf & this study & $467597 \mathrm{mE} 5387160 \mathrm{mN}$ & 435 & Dolerite & $\begin{array}{l}\text { WET } \\
\text { OB0110 }\end{array}$ & 2 & & 1 \\
\hline $10 / 12 / 02$ & Archers Sugarloaf & this study & $467759 \mathrm{mE} 5387242 \mathrm{mN}$ & 430 & Dolerite & $\begin{array}{l}\text { WET } \\
\text { OB0110 }\end{array}$ & 1 & & 1 \\
\hline $10 / 12 / 02$ & Warners Sugarloaf & $\begin{array}{l}\text { N. Roberts (this } \\
\text { study) }\end{array}$ & $\begin{array}{l}470277 \mathrm{mE} 5386284 \mathrm{mN} \\
41^{\circ} 40^{\prime} \mathrm{S} 146^{\circ} 38^{\prime} \mathrm{E}\end{array}$ & 450 & Dolerite & $\begin{array}{l}\text { WET } \\
\text { OB0110 }\end{array}$ & 5 & 521463 & 1 \\
\hline $10 / 12 / 02$ & Jackeys Creek FR & this study & $470474 \mathrm{mE} 5386494 \mathrm{mN}$ & 440 & $\begin{array}{l}\text { Permian } \\
\text { mudstone }\end{array}$ & $\begin{array}{l}\text { WET VIM- } \\
0011\end{array}$ & 13 & & 1 \\
\hline $11 / 12 / 02$ & Warners Sugarloaf & $\begin{array}{l}\text { N. Roberts (this } \\
\text { study) }\end{array}$ & $\begin{array}{l}469875 \mathrm{mE} 5385927 \mathrm{mN} \\
41^{\circ} 40^{\prime} \mathrm{S} 146^{\circ} 38^{\prime} \mathrm{E}\end{array}$ & 435 & Dolerite & $\begin{array}{l}\text { WET } \\
\text { DEL0100 }\end{array}$ & 3 & 521464 & 1 \\
\hline $11 / 12 / 02$ & Meander River & $\begin{array}{l}\text { M. Wapstra (this } \\
\text { study) }\end{array}$ & $\begin{array}{l}463447 \mathrm{mE} 5381741 \mathrm{mN} \\
41^{\circ} 42^{\prime} \mathrm{S} 146^{\circ} 33^{\prime} \mathrm{E}\end{array}$ & 510 & $\begin{array}{l}\text { Dolerite } \\
\text { talus }\end{array}$ & $\begin{array}{l}\text { WET- } \\
\text { DEL1000 }\end{array}$ & 5 & 521468 & 1 \\
\hline $11 / 12 / 02$ & Meander River & this study & $461997 \mathrm{mE} 5380691 \mathrm{mN}$ & 590 & $\begin{array}{l}\text { Dolerite } \\
\text { talus }\end{array}$ & $\begin{array}{l}\text { WET- } \\
\text { DEL0110 }\end{array}$ & 18 & & 1 \\
\hline $11 / 12 / 02$ & East of Meander River & $\begin{array}{l}\text { M. Wapstra (this } \\
\text { study) }\end{array}$ & $\begin{array}{l}462859 \mathrm{mE} 5380724 \mathrm{mN} \\
41^{\circ} 43^{\prime} \mathrm{S} 146^{\circ} 33^{\prime} \mathrm{E}\end{array}$ & 610 & $\begin{array}{l}\text { Dolerite } \\
\text { talus }\end{array}$ & $\begin{array}{l}\text { WET- } \\
\text { DEL0111 }\end{array}$ & 7 & 521465 & 1 \\
\hline $11 / 12 / 02$ & Meander River & this study & $463980 \mathrm{mE} 5382231 \mathrm{mN}$ & 465 & $\begin{array}{l}\text { Dolerite } \\
\text { talus }\end{array}$ & $\begin{array}{l}\text { WET- } \\
\text { DEL0111 }\end{array}$ & 3 & & 1 \\
\hline $18 / 12 / 02$ & New Rd, Franklin & $\begin{array}{l}\text { N. Roberts (this } \\
\text { study) }\end{array}$ & $\begin{array}{l}495197 \mathrm{mE} 5230445 \mathrm{mN} \\
41^{\circ} 04^{\prime} \mathrm{S} 146^{\circ} 56^{\prime} \mathrm{E}\end{array}$ & 435 & Dolerite & $\begin{array}{l}\text { WET } \\
\text { DEL0110 }\end{array}$ & 5 & 521466 & 1 \\
\hline $18 / 12 / 02$ & New Rd, Franklin & this study & $495195 \mathrm{mE} 5230252 \mathrm{mN}$ & 440 & Dolerite & $\begin{array}{l}\text { WET } \\
\text { DEL0110 }\end{array}$ & 2 & & 1 \\
\hline $18 / 12 / 02$ & $\begin{array}{l}\text { Blue Gum Hill, Glen } \\
\text { Huon }\end{array}$ & $\begin{array}{l}\text { N. Roberts (this } \\
\text { study) }\end{array}$ & $\begin{array}{l}491200 \mathrm{mE} 5232900 \mathrm{mN} \\
41^{\circ} 03^{\prime} \mathrm{S} 146^{\circ} 33^{\prime} \mathrm{E}\end{array}$ & 470 & Dolerite & $\begin{array}{l}\text { WET- } \\
\text { REG1001 }\end{array}$ & 5 & 521467 & 1 \\
\hline
\end{tabular}

${ }^{1}$ For records with supporting specimens in $\mathrm{HO}$, the locality is listed as it appears on the herbarium sheet.

${ }^{2}$ For records with supporting specimens in $\mathrm{HO}$, only the first collector listed on the herbarium sheet is shown.

${ }^{3}$ All grid references are in AMG66 coordinate system.

${ }^{4}$ For records with supporting specimens in $\mathrm{HO}$, the latitude/longitude recorded by $\mathrm{HO}$ is included.

${ }^{5}$ Forest type code is taken from North et al. (1998).

${ }^{6}$ Precision codes: 1 (precise to within $50 \mathrm{~m}$ radius (or nearest second) e.g., GPS reading or 6-figure grid reference); 2 (falling within a $1 \mathrm{~km}$ radius (or nearest minute) e.g., a location able to be accurately pinpointed on a map such as the name of a hill; 5 (greater than $25 \mathrm{~km}$ radius) e.g., location given as a region, rather than point locality.

7 Specimens from the same site are also held at National Herbarium of Victoria (type specimen) with duplicates at Royal Botanic Gardens, Kew and Botanischer Garten und Botanisches Museum, Berlin-Dahlem.

${ }^{8}$ Specimens from the same site but held on different herbarium sheets.

9 The specimen at HO has a date of Dec 1890, but specimens in National Herbarium of Victoria are dated 16/11/1890.

${ }^{10}$ Precise locality not known but identification confirmed by $\mathrm{HO}$ (see text for details). 